\title{
THE EFFECT OF PHOSPHORUS AND ZINC ON YIELD AND ON SOME AGRONOMIC CHARACTERISTICS OF COTTON (Gossypium hirsutum L.)
}

\author{
HALILOGLU, H. \\ Department of Field Crops, Faculty of Agriculture, Harran University, Sanliurfa, Turkey \\ (e-mail: haliloglu@harran.edu.tr; phone: +90-505-318-3658) \\ (Received 22 $2^{\text {nd }}$ Nov 2018; accepted $25^{\text {th }}$ Jan 2019)
}

\begin{abstract}
This study was conducted to determine the effect of Phosphorus (P) i.e. $\left(\mathrm{P}_{0}=\right.$ Control, $\mathrm{P}_{40}=40$, $\mathrm{P}_{80}=80$, and $\left.\mathrm{P}_{120}=120 \mathrm{~kg} \mathrm{ha}^{-1}\right)$ and Zinc $(\mathrm{Zn})$ i.e. $\left(\mathrm{Zn}_{0}=\right.$ Control, $\mathrm{Zn}_{05}=5, \mathrm{Zn}_{10}=10$, and $\left.\mathrm{Zn}_{15}=15 \mathrm{~kg} \mathrm{ha}^{-1}\right)$ on yield and on some agronomic characteristics of cotton (Gossypium hirsutum L.) Adiyaman, Turkey. The field experiments were arranged in a randomized complete block with a split plot design with three replications in years of 2011 and 2012. P and $\mathrm{Zn}$ treatments were applied in main and sub-plots, respectively. Cotton cultivar of Stoneville-453 was used in the experiment. Based on the results, phosphorus and zinc applications increased the seed cotton yield. The highest plant height was obtained from the interaction of $\mathrm{P}_{80} \times \mathrm{Zn}_{5}$ and the highest number of bolls was taken from the interaction of $\mathrm{P}_{80} \mathrm{X}$ $\mathrm{Zn}_{10}$. In terms of the number of monopodial branches, statistically significant differences were found in both years, but this significance was not stable over the years. It was concluded that the combined treatments of phosphorus and zinc did not have a significant effect on the boll weight, boll seed cotton weight and ginning outturn. The effect of fertilizers on the number of sympodial branches and 100 seed weight were significant in the first year but not significant in the second year.
\end{abstract}

Keywords: sympodial branch, agronomic traits, ginning, interaction, replications

\section{Introduction and literature review}

In addition to being the main source of natural fiber, cotton is a plant that has an important place in global agriculture and trade with its oil, meal, and other by-products obtained from its seed. Cottonseed pulp is also used in animal nutrition. Along with the developing textile industry, the importance of cotton production in the world economy is increasing gradually. Fertilizer is an important input in cotton production and it has become a necessity for farmers to use for a profitable production. An important component of profitable cotton production is an adequate and balanced fertilization. In the case of cotton and most plants various yields are obtained due to the various growing conditions in different regions. It is necessary to apply cultural measures such as fertilization, tillage, and diseases and pest control as well as sowing, seedbed preparation, and other managements for higher yielding.

Today, the most applied fertilizer of cotton plant is nitrogen, the second one, phosphorus $(\mathrm{P})$ is also one of the essential elements for plant development. Zinc and Phosphorus are important plant nutrients affecting plant growth directly. Phosphorus increases boll development by affecting the flower formation and fertilization biology in cotton. Despite the continuous addition of phosphorus from the organic and inorganic sources to the heavily cultivated soils, the phosphorus level of the soil is insufficient for profitable crop production. $\mathrm{P}$ is an essential element for metabolic functions and vital structures in plants. It is especially vital in early root development, photosynthesis, cell division, energy transfer, early boll development and early maturity (Stewart, 1998).

Phosphorus deficiency leads to deterioration of plant membranes and decreases energy transfer in the plant (Oosterhuis et al., 2007). P deficiency is one of the most 
important factors limiting the yield in plant production, especially in calcareous alkaline soils. Particularly above $\mathrm{pH} 7$, phosphorus in the soil is fixed by cations such as calcium in the soil to form insoluble salts (Zhou et al., 2001). The phosphorus, which turns into salt, becomes useless for the plants (Castro and Torrent, 1995).

Phosphorous fertilizers, unlike nitrogen fertilizers, are fixed very tightly in the soil. Plants rarely intake more than $20 \%$ of the applied phosphorus. However, this rate is as high as $60 \%$ in nitrogen. Phosphorous fertilizers turn out to be beneficial for plants faster in soils with a $\mathrm{pH}$ of 5.5-7. The plant cannot sufficiently utilize it, as it is fixed too tightly under these $\mathrm{pH}$ degrees. These fertilizers are more beneficial when supplied with lime to acidic soils. As the lime prevents phosphorus to be fixed by minerals like iron and aluminum (Aydemir, 1982).

Phosphorous fertilizers can affect significantly the increase of the number of flowers and bolls, the size of bolls, and early maturity rather than the vegetative growth of cotton. It is claimed that phosphorus helps blooming, bearing fruits, and increases the yield in cotton, and that phosphorus deficiency in the soil results in the reduction of plant height as well as seed cotton yield by $30 \%$ (Şenel, 1980).

Crop yield is limited by the low levels of micronutrient minerals such as zinc ( $\mathrm{Zn})$ especially in arid and semi-arid regions of calcareous soils (Cakmak et al., 1999). Zinc is the most preferred micronutrient element to cotton. That is important in regulating the chlorophyll content and assimilation rate of the cotton leaf (Weir et al., 1996). Zinc plays an important role in some enzyme systems and catalyzes the process of disintegration in the plant cell. Moreover, it is also vital in the structural change of carbohydrates, chlorophyll formation and growth-promoting substances. Zinc also prevents withering by promoting water intake (Price, 1970). It was reported that the critical limit of zinc in the field soil is $0.5 \mathrm{ppm}$ (Linsday and Norwel, 1978), and application of zinc as $\mathrm{ZnSO}_{4}$ increases seed cotton yield significantly comparing nonapplied control plot and a $25 \mathrm{~kg} \mathrm{ha}^{-1} \mathrm{ZnSO}_{4}$ application gives the highest yield (Sharma and Gupta, 1988), furthermore, NPK+Zn application significantly increases the seed cotton yield and the number of bolls (Prasad and Prasad, 1994). 44 and $75 \mathrm{~kg} \mathrm{ha}^{-1}$ phosphorous fertilization with $40 \mathrm{ppm}$ foliar zinc application 75 and 90 days after sowing resulted in an increase in the number of bolls, boll weight, 100 seed weight, and seed cotton yield in cotton plants (Sawan et al., 1997). In addition, Soomro et al. (2000) also reported that due to a $5 \mathrm{~kg} \mathrm{ha}^{-1}$ zinc sulfate application the cotton increased the number of bolls, boll weight, seed index, and seed cotton yield compared to the control. Zinc treatment was reported to increase the cotton yield compared to the control (Sawan et al., 2001) and phosphorus and zinc applications increase100 seed weight, seed cotton yield, and fiber yield (Elwan et al., 2002). Nevertheless, it was also stated that zinc application increased plant height the same treatment in soil with high $\mathrm{pH}$ and phosphorus content did not affect the yield (Ören and Başal, 2006). Panayotova et al. (2017) observed that $0,40,80,120$, and $160 \mathrm{~kg} \mathrm{ha}^{-1} \mathrm{P}$ applications, increased the seed cotton yield from 5.02 to $11.71 \%$, the number of bolls from 3.0 to $25.9 \%$, and plant height significantly.

Foliar zinc application twice i.e. $\left(0\right.$ and $\left.58 \mathrm{~g} \mathrm{ha}^{-1}\right) 70$ and 85 days after sowing, and the foliar phosphorus application twice i.e. (control, 576, 1152, and $1728 \mathrm{~g} \mathrm{ha}^{-1}$ ) 80 and 95 days after sowing increased seed cotton yield, number of bolls, 100 seed weight, and fiber yield (Sawan et al., 2008). Zinc treatments of the $0,5,7.5,10$, and $12.5 \mathrm{~kg} \mathrm{ha}^{-1}$ doses a $7.5 \mathrm{~kg} \mathrm{ha}^{-1}$ was stated to be the most effective zinc dose, and this zinc ratio increased 100 seed weight and seed cotton yield (Ahmed et al., 2010). 
This study aimed to assess the effect of phosphorus and zinc applications on the yield and agronomic characteristic of cotton in South East Anatolia.

\section{Materials and methods}

Field trials were carried out in zinc deficient soils of Old Hosni Mansur (Eskihüsnümansur) village of Adiyaman in Turkey in 2011 and 2012 growing seasons. Stoneville 453 cotton cultivar was employed as plant material.

Field trials were set up at the same location in both years, but on the different parts of experimental field showing Zn deficiency. Some soil properties of the experimental area were given in Table 1.

Table 1. Soil properties of the field

\begin{tabular}{c|c|c}
\hline Soil properties & $\mathbf{2 0 1 1}$ & $\mathbf{2 0 1 2}$ \\
\hline Saturation (\%) & 55 & 57 \\
$\mathrm{Ec}_{25} 10^{3}(\mathrm{mmhos} / \mathrm{cm})$ & 0.083 & 0.079 \\
$\mathrm{pH}(1: 2: 5)$ & 7.60 & 7.45 \\
$\mathrm{P}_{2} \mathrm{O}_{5}\left(\mathrm{~kg} \mathrm{ha}^{-1}\right)$ & 8 & 21 \\
$\mathrm{~K}_{2} \mathrm{O}_{5}\left(\mathrm{~kg} \mathrm{ha}^{-1}\right)$ & 799 & 691 \\
Organic matter $(\%)$ & 1.4 & 2.03 \\
Lime Sodium N (me/L) & 23.9 & 24.1 \\
$\mathrm{Cu}(\mathrm{mg} / \mathrm{L})$ & 2.48 & 2.43 \\
$\mathrm{Mn}(\mathrm{mg} / \mathrm{L})$ & 3.18 & 3.08 \\
$\mathrm{Fe}(\mathrm{mg} / \mathrm{L})$ & 7.05 & 6.94 \\
$\mathrm{Zn}(\mathrm{mg} / \mathrm{L})$ & 0.27 & 0.25 \\
\hline
\end{tabular}

Anonymous, 2012a

Adiyaman is located at the transitional zone between coastal and continental climate conditions. Adiyaman province is located at $37^{\circ} 45^{\prime}$ north latitude and $38^{\circ} 16^{\prime}$ ' east longitude with an altitude of $672 \mathrm{~m}$. Field trials were located at $37^{\circ} 41^{\prime} 47^{\prime}$ 'north latitude $38^{\circ} 20^{\prime} 55^{\prime}$ east longitude with a $547 \mathrm{~m}$ altitude from sea level (Figure 1).

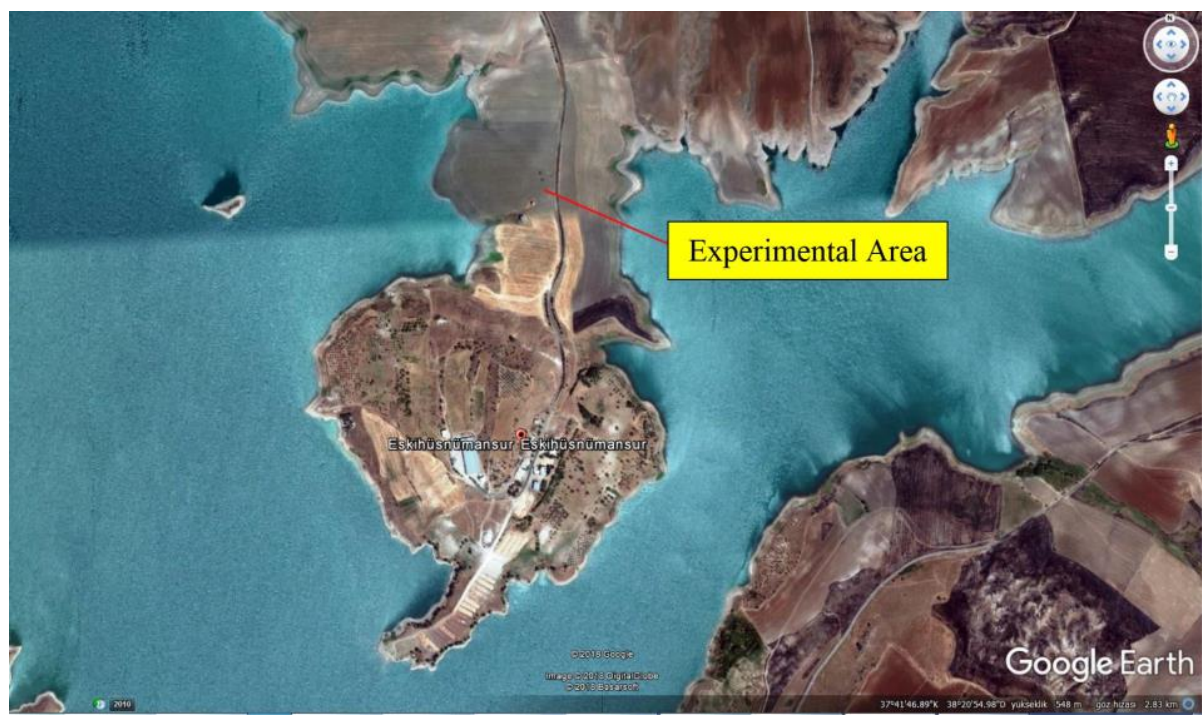

Figure 1. The map of the experimental area 
In the 2011 growing season, the average temperatures were between $10.2^{\circ} \mathrm{C}$ to $32.3^{\circ} \mathrm{C}$ and the maximum temperatures were between $20.2^{\circ} \mathrm{C}$ and $42.5^{\circ} \mathrm{C}$, while in the 2012 cultivation season the average temperatures were between $10.4^{\circ} \mathrm{C}$ to $32.5^{\circ} \mathrm{C}$ and the maximum temperature was between $20.5^{\circ} \mathrm{C}$ and $43.7^{\circ} \mathrm{C}$ (Table 2).

Table 2. The official record of Meteorology Directory, Adiyaman, Turkey.

\begin{tabular}{|c|c|c|c|c|c|c|c|c|c|c|}
\hline \multicolumn{11}{|c|}{2011} \\
\hline & March & April & May & June & July & Aug. & Sept. & Oct. & Nov. & Annual \\
\hline Av. Temp. & 10.2 & 16.1 & 21.3 & 26.4 & 32.3 & 31.4 & 25.4 & 17.6 & 10.4 & 17.6 \\
\hline Max Temp. & 21.4 & 27.9 & 33.0 & 37.2 & 42.5 & 41.3 & 36.0 & 31.2 & 20.2 & 42.5 \\
\hline Min Temp. & 0.4 & 2.7 & 5.7 & 13.3 & 18.0 & 20.7 & 15.3 & 5.8 & 0.0 & -3.8 \\
\hline Total Precip. & 80.6 & 25.4 & 36.5 & 13.5 & 0.0 & 3.5 & 0.4 & 44.1 & 70.8 & 457.7 \\
\hline \multicolumn{11}{|c|}{2012} \\
\hline Av. Temp. & 10.8 & 16.7 & 21.8 & 29.1 & 31.1 & 32.5 & 25.6 & 19.4 & 10.4 & 17.9 \\
\hline Max Temp. & 21.7 & 27.2 & 37.1 & 40.2 & 41.0 & 43.7 & 38.3 & 32.4 & 20.5 & 43.7 \\
\hline Min Temp. & 2.0 & 4.0 & 9.0 & 15.3 & 20.4 & 20.8 & 12.9 & 10.0 & 1.7 & -6.3 \\
\hline Total Precip. & 62.3 & 64.9 & 33.9 & 0.1 & 0.0 & 0.1 & 0.3 & 82.8 & 90.7 & 678.0 \\
\hline \multicolumn{11}{|c|}{ Average temperatures for 10 years period (2002-2012) } \\
\hline Av. Temp. & 9.8 & 14.7 & 20.2 & 26.3 & 30.6 & 30.1 & 25.4 & 15.8 & 11.8 & 16.7 \\
\hline Max Temp. & 24.7 & 30 & 36 & 40 & 44 & 43.5 & 40 & 35 & 28.2 & 44 \\
\hline Min Temp. & -6 & -2 & 6 & 10.6 & 16.7 & 16.3 & 10.2 & 2.2 & -3.2 & -14.6 \\
\hline Total Precip. & 111.3 & 82.9 & 51.4 & 5.9 & 1.5 & 0.8 & 3.8 & 30.6 & 76.7 & 798.1 \\
\hline
\end{tabular}

Anonymous, 2012b

In the field trials, phosphorus (Triple Super Phosphate), and zinc sulfate heptahydrate $\left(\mathrm{ZnSO}_{4} .7 \mathrm{H}_{2} \mathrm{O}\right)(22 \%)$ were used as treatments. The experiments were carried out by split plot in randomized complete blocks with 3 replications. $\mathrm{P}$ doses i.e. ( $\mathrm{P}_{0}=$ Control, $\mathrm{P}_{40}=40, \mathrm{P}_{80}=80$, and $\left.\mathrm{P}_{120}=120 \mathrm{~kg} \mathrm{ha}^{-1}\right)$ formed main plots and $\mathrm{Zn}$ treatments i.e. $\left(\mathrm{Zn}_{0}=\right.$ Control, $\mathrm{Zn}_{05}=5, \mathrm{Zn}_{10}=10$, and $\mathrm{Zn}_{15}=15 \mathrm{~kg} \mathrm{ha}^{-1}$ ) formed sub-plots. Each plot had a length of $12 \mathrm{~m}$ and consisted of 6 rows. There were $2 \mathrm{~m}$ alleys between plots, and $3 \mathrm{~m}$ between blocks $70 \mathrm{~cm}$ inter rows and $15 \mathrm{~cm}$ intra row spacing were allowed. Sowing was practiced on $22^{\text {nd }}$ April in 2011, and $27^{\text {th }}$ April in 2012, by a pneumatic drill. In total, a $160 \mathrm{~kg} \mathrm{ha}^{-1}$ pure nitrogen was applied. Half of the nitrogen was given during the sowing and the remaining half was given by the lister tool just before the first irrigation. All of the phosphorus was given during the sowing by drill and the Zinc sulfate heptahydrate $\left(\mathrm{ZnSO}_{4} .7 \mathrm{H}_{2} \mathrm{O}\right)$ was manually given into neighboring rows located $5-6 \mathrm{~cm}$ apart and depth from cotton seeded rows.

Irrigation was practiced seven times in 2011 and 8 times in 2012 applying $840 \mathrm{~mm}$ and $960 \mathrm{~mm}$ for consecutive years, respectively. Furrow irrigation method was performed. Agronomic managements were carried out based on common practices employed in the region. No spraying was carried out against pests in either year.

Seed cotton harvests were done manually (handpicking) on $23^{\text {th }}$ September 2011 and $17^{\text {th }}$ September 2012, respectively. Seed cotton yield $\left(\mathrm{kg} \mathrm{plot}^{-1}\right)$ was scored taking into account two rows in the middle of 10 meters in each plot $\left(10 \mathrm{~m} \times 1.4 \mathrm{~m}=14 \mathrm{~m}^{2}\right)$ excluding the one-meter area from both ends of the plot. The ginning outturn (\%) was determined by the ginning of $0.5 \mathrm{~kg}$ of seed cotton collected from each plot. Plant height $(\mathrm{cm})$, number of monopodial branches (per plant $\left.{ }^{-1}\right)$, number of sympodial branches (per plant ${ }^{-1}$ ), and number of bolls (per plant ${ }^{-1}$ ) were calculated by scoring in 10 randomly selected plants in each plot. Boll weight $(\mathrm{g})$, boll seed cotton weight $(\mathrm{g})$ and 
100 seed weight $(\mathrm{g})$ were scored by employing 35 boll samples randomly selected from plots just before harvest (Worley et al., 1976).

The data obtained from the experiment was analyzed by using the MINITAB 18 (Minitab Inc., USA) statistical software and analysis of variance was performed according to the split plot test in randomized complete block design and the means were grouped by the Tukey HSD $(\mathrm{p} \leq 0.05)$ test.

\section{Results and Discussion}

In the analysis of variance (ANOVA) according to the combined years of the properties examined in the trial, statistical differences were found between years. Due to that the results of each year were analyzed separately.

$F$ values obtained from the analysis of variance of the traits under study in the experiment were given in Table 3.

Table 3. Statistical significance $(F)$ of some traits in the ANOVA

\begin{tabular}{|c|c|c|c|c|c|c|c|c|c|c|}
\hline & \multicolumn{2}{|c|}{ Seed Cotton Yield } & \multicolumn{2}{|c|}{ Plant Height } & \multicolumn{2}{|c|}{$\begin{array}{c}\text { Monopodial } \\
\text { Branches } \\
\end{array}$} & \multicolumn{2}{|c|}{$\begin{array}{c}\text { Sympodial } \\
\text { Branches } \\
\end{array}$} & \multicolumn{2}{|c|}{$\begin{array}{c}\text { Number of } \\
\text { Bolls }\end{array}$} \\
\hline & 2011 & 2012 & 2011 & 2012 & 2011 & 2012 & 2011 & 2012 & 2011 & 2012 \\
\hline $\mathrm{P}$ & $* *$ & $* *$ & $* *$ & $\mathrm{~ns}$ & $* *$ & $\mathrm{~ns}$ & $* *$ & $\mathrm{~ns}$ & $* *$ & $* *$ \\
\hline $\mathrm{Zn}$ & $* *$ & $* *$ & $* *$ & $*$ & $* *$ & $* *$ & ns & $\mathrm{ns}$ & $\mathrm{ns}$ & $*$ \\
\hline \multirow[t]{3}{*}{ PxZn } & $* *$ & $* *$ & $* *$ & $* *$ & $* *$ & $* *$ & $* *$ & ns & $*$ & $* *$ \\
\hline & \multicolumn{2}{|c|}{ Boll Weight } & \multicolumn{2}{|c|}{$\begin{array}{c}\text { Boll Seed Cotton } \\
\text { Weight }\end{array}$} & \multicolumn{2}{|c|}{ Ginning Outturn } & \multicolumn{2}{|c|}{$\begin{array}{c}100 \text { Seed } \\
\text { Weight }\end{array}$} & & \\
\hline & 2011 & 2012 & 2011 & 2012 & 2011 & 2012 & 2011 & 2012 & & \\
\hline $\mathrm{P}$ & ns & ns & ns & ns & ns & ns & $*$ & ns & & \\
\hline $\mathrm{Zn}$ & ns & ns & ns & ns & ns & ns & ns & ns & & \\
\hline PxZn & ns & ns & ns & ns & ns & ns & $*$ & ns & & \\
\hline
\end{tabular}

Seed cotton yield $\left(\mathrm{kg} \mathrm{ha}^{-1}\right)$, plant height $(\mathrm{cm})$, number of monopodial branches (no. plant $^{-1}$ ), number of sympodial branches (no. plant ${ }^{-1}$ ), number of bolls (no. plant ${ }^{-1}$ ), boll weight $(\mathrm{g})$, boll seed cotton weight $(\mathrm{g})$, ginning outturn $(\%)$ and 100 seed weight $(\mathrm{g})$ were given in Tables 4, 5 and 6.

\section{Seed Cotton Yield ( $\left.\mathrm{kg} \mathrm{ha}^{-1}\right)$}

Table 4 showed that the lowest seed cotton yield in 2011 was obtained from the control plot of $\mathrm{P}_{0} \times \mathrm{Zn}_{0}$ with as $3401 \mathrm{~kg} \mathrm{ha}^{-1}$ and the highest yield was provided by the $\mathrm{P}_{120} \times \mathrm{Zn}_{15}$ interaction with $4595 \mathrm{~kg} \mathrm{ha}^{-1}$, while the lowest seed cotton yield in 2012 was again obtained from the control plot, of $\mathrm{P}_{0} \times \mathrm{Zn}_{0}$, with $2993 \mathrm{~kg} \mathrm{ha}^{-1}$ and the highest yield was provided by the $\mathrm{P}_{8} \times \mathrm{Zn}_{1}$ interaction with $4189 \mathrm{~kg} \mathrm{ha}^{-1}$.

The lowest yield provided by the control plots in both years showed that phosphorus and zinc had some positive effects on yield. However, the highest yield varied in both years, and this fluctuation was based on various climatic and soil factors.

Sawan et al. (2006) found that phosphorus application at three concentrations (i.e. 600,1200 , and $1800 \mathrm{ppm}$ P) significantly increased the seed cotton yield compared to control (9.49\% -17.12\%). Meanwhile, Singh et al. (2013) indicated that phosphate deficiency decreased plant growth and photosynthesis, thereby reduced biomass 
accumulation and yield. Russell (2001) claimed that phosphorus, as part of the cell nucleus, was important for cell division and the development of meristematic tissue, and therefore had a stimulating effect to increase the number of bolls and flowers per plant.

Table 4. Means and the groups of seed cotton yield $\left(\mathrm{kg} \mathrm{ha}^{-1}\right)$, plant height (cm) and monopodial branches (per plant)

\begin{tabular}{|c|c|c|c|c|c|c|c|}
\hline \multirow{2}{*}{\multicolumn{2}{|c|}{$\begin{array}{c}\text { P X Zn } \\
\text { Interactions }\end{array}$}} & \multicolumn{2}{|c|}{$\begin{array}{c}\text { Seed Cotton Yield } \\
\left(\mathrm{kg} \mathrm{ha}^{-1}\right)\end{array}$} & \multicolumn{2}{|c|}{$\begin{array}{l}\text { Plant Height } \\
\text { (cm) }\end{array}$} & \multicolumn{2}{|c|}{$\begin{array}{c}\text { Monopodial Branches } \\
\text { (per plant) }\end{array}$} \\
\hline & & 2011 & 2012 & 2011 & 2012 & 2011 & 2012 \\
\hline \multirow{4}{*}{$\mathrm{P}_{\mathrm{o}}$} & $\mathrm{Zn}_{0}$ & $3401 \mathrm{e}^{*}$ & $2993 h^{*}$ & $74.4 \mathrm{f}^{*}$ & $73.8 \mathrm{a}^{*}$ & $0.8 \mathrm{de}^{*}$ & $0.5 \mathrm{a}^{*}$ \\
\hline & $\mathrm{Zn}_{5}$ & 3787 cde & $3188 \mathrm{fgh}$ & $76.2 \mathrm{cdef}$ & $68.2 \mathrm{bcd}$ & $1.0 \mathrm{bcd}$ & $0.1 \mathrm{e}$ \\
\hline & $\mathrm{Zn}_{10}$ & $3461 \mathrm{e}$ & 3340 ef & $75.6 \mathrm{def}$ & $67.8 \mathrm{bcd}$ & $1.3 \mathrm{ab}$ & $0.3 \mathrm{bcd}$ \\
\hline & $\mathrm{Zn}_{15}$ & $3434 \mathrm{e}$ & $3127 \mathrm{fgh}$ & 74.6 ef & $68.2 \mathrm{bcd}$ & $1.3 \mathrm{ab}$ & 0.2 cde \\
\hline \multirow{4}{*}{$\mathrm{P}_{40}$} & $\mathrm{Zn}_{0}$ & $4136 \mathrm{abcd}$ & $3213 \mathrm{fgh}$ & 77.4 b-f & $72.7 \mathrm{ab}$ & $0.8 \mathrm{de}$ & 0.2 cde \\
\hline & $\mathrm{Zn}_{5}$ & 4158 abcd & $3068 \mathrm{gh}$ & 76.9 b-f & $70.2 \mathrm{abc}$ & 0.9 cde & $0.3 \mathrm{bcd}$ \\
\hline & $\mathrm{Zn}_{10}$ & 3706 de & $3006 \mathrm{~h}$ & $75.4 \mathrm{def}$ & $65.6 \mathrm{~cd}$ & $1.2 \mathrm{ab}$ & 0.2 cde \\
\hline & $\mathrm{Zn}_{15}$ & 3888 bcde & $3575 \mathrm{~cd}$ & $78.6 \mathrm{abcd}$ & $65.5 \mathrm{~cd}$ & $0.8 \mathrm{de}$ & $0.3 \mathrm{bc}$ \\
\hline \multirow{4}{*}{$\mathrm{P}_{80}$} & $\mathrm{Zn}_{0}$ & 4046 bcd & $3259 \mathrm{efg}$ & $79.9 \mathrm{abc}$ & $64.2 \mathrm{~d}$ & $1.1 \mathrm{abc}$ & 0.2 cde \\
\hline & $\mathrm{Zn}_{5}$ & $3978 \mathrm{bcd}$ & $3748 b c$ & $82.4 \mathrm{a}$ & $73.3 \mathrm{a}$ & $1.0 \mathrm{bcd}$ & $0.3 \mathrm{bc}$ \\
\hline & $\mathrm{Zn}_{10}$ & $4182 \mathrm{abcd}$ & $4189 \mathrm{a}$ & $78.9 \mathrm{abcd}$ & $69.8 \mathrm{abc}$ & $1.4 \mathrm{a}$ & $0.3 \mathrm{bcd}$ \\
\hline & $\mathrm{Zn}_{15}$ & $4340 \mathrm{ab}$ & 3904 b & 78.0 b-f & $70.1 \mathrm{abc}$ & $0.7 \mathrm{e}$ & $0.3 \mathrm{bc}$ \\
\hline \multirow{4}{*}{$\mathrm{P}_{120}$} & $\mathrm{Zn}_{0}$ & $4246 a b c$ & 3452 de & $79.1 \mathrm{abcd}$ & $71.2 \mathrm{ab}$ & $1.1 \mathrm{abc}$ & $0.4 \mathrm{ab}$ \\
\hline & $\mathrm{Zn}_{5}$ & 3736 cde & $3671 \mathrm{~cd}$ & $78.5 \mathrm{a}-\mathrm{e}$ & $67.8 \mathrm{bcd}$ & $1.4 \mathrm{a}$ & $0.3 \mathrm{bcd}$ \\
\hline & $\mathrm{Zn}_{10}$ & 3761 cde & $3659 \mathrm{~cd}$ & $75.5 \mathrm{def}$ & $70.3 \mathrm{abc}$ & $1.0 \mathrm{bcd}$ & $0.3 \mathrm{bc}$ \\
\hline & $\mathrm{Zn}_{15}$ & $4595 \mathrm{a}$ & 3329 ef & $80.3 \mathrm{ab}$ & $70.9 \mathrm{ab}$ & $1.3 \mathrm{ab}$ & $0.2 \mathrm{de}$ \\
\hline \multicolumn{2}{|c|}{ C.V. $\%$} & 4.09 & 4.60 & 2.14 & 5.91 & 10.22 & 18.07 \\
\hline
\end{tabular}

*Means followed by different letters within columns are significantly different $(\mathrm{p} \leq 0.05)$

Zinc might have a positive effect on the photosynthetic activity of leaves (Welch, 1995), which enhances the mobilization of photosynthetic assimilates and directly affected the boll weight. In addition, zinc was required for the synthesis of tryptophan, a precursor of indole-3-acetic acid (Oosterhuis et al., 1991). This is the main hormone that prevents the separation of bolls and bract leaves of the plant. Thus, this increases the number of bolls in the plant, consequently, the seed cotton yield (Rathinavel et al., 2000).

Similar findings suggested that zinc and phosphorus applications increased the seed cotton yield (Sharma and Gupta, 1988; Sawan et al., 1997, 2001; Soomro et al., 2000; Elwan et al., 2002; Mamatha, 2007; Ahmad et al., 2009; Ahmed et al., 2010; Saleem et al., 2010; Emara, 2016; Sawan, 2018).

\section{Plant Height (cm)}

Table 4 showed that the lowest plant height in 2011 was obtained from the control plot of $\mathrm{P}_{0} \times \mathrm{Zn}_{0}$, with $74.4 \mathrm{~cm}$ and the highest plant height was provided by the $\mathrm{P}_{80} \times \mathrm{Zn}_{5}$ interaction with $82.4 \mathrm{~cm}$, while the lowest plant height in 2012 was obtained from the plot $\mathrm{P}_{80} \times \mathrm{Zn}_{0}$ with $64.2 \mathrm{~cm}$ and the highest plant height was provided by the control plot of $\mathrm{P}_{0} \times \mathrm{Zn}_{0}$ and the plot of $\mathrm{P}_{80} \times \mathrm{Zn}_{5}$ interaction with $73.8 \mathrm{~cm}$ and $73.3 \mathrm{~cm}$, respectively.

The results revealed that phosphorus and zinc had a statistically significant effect on plant height. The $\mathrm{P}_{80} \times \mathrm{Zn}_{5}$ interaction taking the first rank in both years indicated that this treatment increased plant height. This result is supported by the Neilsen and 
Hogue's (1986) finding claiming that in phosphorous-rich soils phosphate had low solubility forms, such as the compound $\mathrm{Zn}_{3}\left(\mathrm{PO}_{4}\right)_{3}$ which prevents the transport of zinc to the above-ground organs of the plant, hence, the growth decreases due to the lesser amounts of $\mathrm{Zn}$ in the plant tops. Ören and Başal (2012) and Mamatha (2007) observed that zinc applications and Saleem et al. (2010) observed that P applications increased plant height compared to control.

\section{Monopodial Branches (Per Plant)}

Table 4 showed that some statistically significant differences were found in both years of experiment in terms of the number of monopodial branches. In 2011, the lowest number of monopodial branches was in $\mathrm{P}_{80} \times \mathrm{Zn}_{15}$ (0.7 per plant) interaction and the highest number was in $\mathrm{P}_{80} \times \mathrm{Zn}_{10}$ (1.4 per plant) and $\mathrm{P}_{120} \times \mathrm{Zn}_{5}$ (1.4 per plant). In 2012, the lowest number of monopodial branches was obtained from $\mathrm{P}_{0} \times \mathrm{Zn}_{5}$ ( 0.1 per plant) interaction, while the highest number of monopodial branches was obtained from $\mathrm{P}_{0} \times \mathrm{Zn}_{0}(0.5$ per plant $)$ interaction.

In terms of the number of monopodial branches, statistically significant differences were found in both years of experiment. Nonetheless, this difference was not stable but varied depending on years. The difference between the experimental years might be due to soil properties and climatic conditions in the experimental years. Saleem et al. (2010) reported that $90 \mathrm{~kg} \mathrm{ha}^{-1} \mathrm{P}$ application decreased the number of monopodial branches compared to the control.

\section{Sympodial Branches (Per Plant)}

Statistically significant differences were in 2011, but no difference was found in 2012. The lowest number of sympodial branches in 2011 was from the $\mathrm{P}_{40} \times \mathrm{Zn}_{0}$ (11.5 per plant), while the highest number of that was from the $\mathrm{P}_{120} \times \mathrm{Zn}_{15}$ (14.77 per plant) and $\mathrm{P}_{0} \times \mathrm{Zn}_{5}$ (14.4 per plant) interactions, whereas in 2012, the lowest number of sympodial branches was obtained from the interaction of $\mathrm{P}_{0} \mathrm{x} \mathrm{Zn}_{5}$ (7.1 per plant), while the highest number of sympodial branches was obtained from $\mathrm{P}_{8} \times \mathrm{Zn}_{0.5}$ and $\mathrm{P}_{8} \times \mathrm{Zn}_{1}$ (11.2 per plant) interactions (Table 5).

The results indicated that phosphorus and zinc applications were important in 2011 but they were non-significant in 2012 for sympodial branches, and this difference derived from climate and soil conditions. This showed that there was no stability derived from the effects of phosphorus and zinc on the number of sympodial branches. Ahmad et al. (2009) and Mamatha (2007) reported that zinc applications, both $34 \mathrm{~kg} \mathrm{ha}^{-1}$ and $50 \mathrm{~kg} \mathrm{ha}^{-1}$ increased the number of sympodial branches per plant compared to control.

\section{Number of Bolls (Per Plant)}

From Table 5, it is evident that the lowest number of bolls occured from $\mathrm{P}_{40} \times \mathrm{Zn}_{0}$ (12.7 per plant) interaction and the highest number from $\mathrm{P}_{80} \times \mathrm{Zn}_{10}$ (17.7 per plant) interaction in 2011, while in 2012, the lowest number of bolls was obtained from $\mathrm{P}_{40} \times \mathrm{Zn}_{5}$ (8.8 per plant) interactions and the highest number was obtained from $\mathrm{P}_{80} \times \mathrm{Zn}_{5}$ (11.40 per plant) and $\mathrm{P}_{80} \times \mathrm{Zn}_{10}$ (11.0 per plant) interactions.

These results revealed that phosphorus and zinc interaction had a statistically significant effect on the number of bolls and the highest effect was obtained from the interactions of $\mathrm{P}_{80} \times \mathrm{Zn}_{5}$ and $\mathrm{P}_{80} \times \mathrm{Zn}_{10}$. Phosphorus and zinc applications can lead to an 
increase in the number of bolls by having a positive effect on flower formation and fertilization biology. The results in the current study number of bolls was similar to that from Prasad and Prasad (1994), Sawan et al. (1997), Soomro et al. (2000), Sawan et al. (2008), and Emara (2016). Furthermore, Ahmad et al. (2009) reported that phosphorus application of $34 \mathrm{~kg} \mathrm{ha}^{-1}$ increases the number of bolls and Mamatha (2007) showed that $50 \mathrm{~kg} \mathrm{ha}^{-1}$ of zinc application increased the number of bolls by $18.88 \%$ compared to control.

Table 5. Means and the groups of sympodial branches (no. plant ${ }^{-1}$ ), number of bolls (per plant) and boll weight $(g)$

\begin{tabular}{|c|c|c|c|c|c|c|c|}
\hline \multirow{2}{*}{\multicolumn{2}{|c|}{ P X Zn Interactions }} & \multicolumn{2}{|c|}{$\begin{array}{c}\text { Sympodial Branches } \\
\text { (per plant) }\end{array}$} & \multicolumn{2}{|c|}{$\begin{array}{c}\text { Number of Bolls } \\
\text { (per plant) }\end{array}$} & \multicolumn{2}{|c|}{$\begin{array}{c}\text { Boll Weight } \\
(\mathrm{g})\end{array}$} \\
\hline & & 2011 & 2012 & 2011 & 2012 & 2011 & 2012 \\
\hline \multirow{4}{*}{$\mathrm{P}_{\mathrm{o}}$} & $\mathrm{Zn}_{0}$ & $13.8 \mathrm{ab}^{*}$ & $11.0^{\mathrm{ns}}$ & $15.9 \mathrm{abc}^{*}$ & $9.4 \mathrm{de}^{*}$ & $6.2^{\mathrm{ns}}$ & $5.9^{\mathrm{ns}}$ \\
\hline & $\mathrm{Zn}_{5}$ & $14.4 \mathrm{a}$ & 7.1 & $15.2 \mathrm{a}-\mathrm{d}$ & 9.1 ef & 6.3 & 6.0 \\
\hline & $\mathrm{Zn}_{10}$ & $13.7 \mathrm{ab}$ & 10.3 & $15.4 \mathrm{abc}$ & $9.8 \mathrm{~cd}$ & 6.4 & 6.1 \\
\hline & $\mathrm{Zn}_{15}$ & $13.5 \mathrm{ab}$ & 10.9 & $15.3 \mathrm{abc}$ & $9.8 \mathrm{~cd}$ & 5.9 & 6.2 \\
\hline \multirow{4}{*}{$\mathrm{P}_{40}$} & $\mathrm{Zn}_{0}$ & $11.5 \mathrm{c}$ & 10.7 & $12.7 \mathrm{~d}$ & $9.1 \mathrm{ef}$ & 6.6 & 6.0 \\
\hline & $\mathrm{Zn}_{5}$ & $13.2 \mathrm{abc}$ & 10.4 & $15.1 \mathrm{a}-\mathrm{d}$ & $9.7 \mathrm{~cd}$ & 6.5 & 6.4 \\
\hline & $\mathrm{Zn}_{10}$ & $12.3 \mathrm{bc}$ & 10.2 & $14.0 \mathrm{~cd}$ & $8.8 \mathrm{f}$ & 6.1 & 6.1 \\
\hline & $\mathrm{Zn}_{15}$ & $13.2 \mathrm{abc}$ & 10.5 & $15.2 \mathrm{abc}$ & $10.2 \mathrm{bc}$ & 6.1 & 6.0 \\
\hline \multirow{4}{*}{$\mathrm{P}_{80}$} & $\mathrm{Zn}_{0}$ & $13.3 \mathrm{abc}$ & 9.7 & $16.9 \mathrm{ab}$ & $9.7 \mathrm{~cd}$ & 6.1 & 6.3 \\
\hline & $\mathrm{Zn}_{5}$ & $13.4 \mathrm{ab}$ & 11.2 & $16.8 \mathrm{ab}$ & $11.4 \mathrm{a}$ & 6.4 & 6.3 \\
\hline & $\mathrm{Zn}_{10}$ & $13.1 \mathrm{abc}$ & 11.2 & $17.7 \mathrm{a}$ & $11.0 \mathrm{a}$ & 6.1 & 6.1 \\
\hline & $\mathrm{Zn}_{15}$ & $13.0 \mathrm{abc}$ & 9.4 & $16.5 \mathrm{abc}$ & $10.4 \mathrm{~b}$ & 6.3 & 6.1 \\
\hline \multirow{4}{*}{$P_{120}$} & $\mathrm{Zn}_{0}$ & $13.8 \mathrm{ab}$ & 10.3 & $15.1 \mathrm{a}-\mathrm{d}$ & $9.9 \mathrm{bcd}$ & 6.3 & 6.4 \\
\hline & $\mathrm{Zn}_{5}$ & $14.0 \mathrm{ab}$ & 9.3 & $15.6 \mathrm{abc}$ & $9.1 \mathrm{ef}$ & 6.4 & 5.9 \\
\hline & $\mathrm{Zn}_{10}$ & $13.1 \mathrm{abc}$ & 9.7 & $14.8 \mathrm{bcd}$ & $9.9 \mathrm{~cd}$ & 6.2 & 6.4 \\
\hline & $\mathrm{Zn}_{15}$ & $14.7 \mathrm{a}$ & 9.8 & $15.1 \mathrm{a}-\mathrm{d}$ & $8.7 \mathrm{f}$ & 6.4 & 6.4 \\
\hline \multicolumn{2}{|c|}{ C.V. \% } & 4.41 & 6.63 & 5.38 & 8.88 & 4.29 & 6.86 \\
\hline
\end{tabular}

"Means followed by different letters within columns are significantly different $(\mathrm{p} \leq 0.05)$ ns non-significant

\section{Boll Weight (g)}

In 2011 and 2012, no significant effect of phosphorus and zinc on the weight of bolls was found (Table 5). Boll weights ranged from 5.9 to $6.4 \mathrm{~g}$ in both years of experiment. Therefore, it can be concluded that phosphorus and zinc had no significant effect on the weight of bolls in the present study.

Nonetheless, these results in terms of boll weight contradict partially with that of Soomro et al. (2000), Mamatha (2007), and Emara (2016) regarding zinc applications increase the weight of bolls. This may be due to the various cultivars employed in the study and zinc and phosphorus doses used in the trials.

\section{Boll Seed Cotton Weight (g)}

In both years, no statistically significant effect of phosphorus and zinc applications on the weight of boll seed cotton was found (Table 6 ). Boll seed cotton weights varied from $4.8 \mathrm{~g}$ to $5.4 \mathrm{~g}$. These results showed that phosphorus and zinc had no significant effect on the weight of boll seed cotton. 


\section{Ginning Outturn (\%)}

From Table 6, no statistically significant effect of phosphorus and zinc on ginning outturn was found in 2011 and 2012. The ginning outturn in 2011 and 2012 varied from 40.8 to $42.3 \%$. These results revealed that phosphorus and zinc had no a significant effect on ginning outturn.

Table 6. Means and the groups of boll seed cotton weight (g), ginning outturn (\%) and 100 seed weight $(g)$

\begin{tabular}{|c|c|c|c|c|c|c|c|}
\hline \multirow{2}{*}{\multicolumn{2}{|c|}{ P X Zn Interactions }} & \multicolumn{2}{|c|}{ Boll Seed Cotton Weight (g) } & \multicolumn{2}{|c|}{ Ginning Outturn (\%) } & \multicolumn{2}{|c|}{100 seed weight $(\mathrm{g})$} \\
\hline & & 2011 & 2012 & 2011 & 2012 & 2011 & 2012 \\
\hline \multirow{4}{*}{$\mathrm{P}_{\mathrm{o}}$} & $\mathrm{Zn}_{0}$ & $4.9^{\mathrm{ns}}$ & $4.7^{\mathrm{ns}}$ & $41.7^{\mathrm{ns}}$ & $41.9^{\mathrm{ns}}$ & $9.9 b^{*}$ & $9.9^{\mathrm{ns}}$ \\
\hline & $\mathrm{Zn}_{5}$ & 4.9 & 4.6 & 41.7 & 41.8 & $9.9 \mathrm{~b}$ & 9.9 \\
\hline & $\mathrm{Zn}_{10}$ & 5.0 & 4.8 & 41.4 & 41.6 & $9.9 \mathrm{~b}$ & 10.3 \\
\hline & $\mathrm{Zn}_{15}$ & 4.9 & 4.9 & 41.5 & 42.3 & $9.6 \mathrm{~b}$ & 9.6 \\
\hline \multirow{4}{*}{$\mathrm{P}_{40}$} & $\mathrm{Zn}_{0}$ & 5.2 & 4.7 & 41.2 & 41.5 & $9.6 \mathrm{~b}$ & 9.6 \\
\hline & $\mathrm{Zn}_{5}$ & 5.2 & 5.4 & 41.2 & 40.8 & $9.9 \mathrm{~b}$ & 9.6 \\
\hline & $\mathrm{Zn}_{10}$ & 4.8 & 4.8 & 41.4 & 42.1 & $9.8 \mathrm{~b}$ & 10.3 \\
\hline & $\mathrm{Zn}_{15}$ & 4.8 & 4.7 & 41.8 & 42.1 & $9.5 \mathrm{~b}$ & 9.8 \\
\hline \multirow{4}{*}{$\mathrm{P}_{80}$} & $\mathrm{Zn}_{0}$ & 5.0 & 4.6 & 42.0 & 42.3 & $9.4 \mathrm{~b}$ & 9.8 \\
\hline & $\mathrm{Zn}_{5}$ & 5.0 & 5.0 & 42.2 & 41.9 & $9.9 \mathrm{~b}$ & 9.8 \\
\hline & $\mathrm{Zn}_{10}$ & 4.9 & 4.8 & 41.1 & 41.0 & $10.0 \mathrm{~b}$ & 9.7 \\
\hline & $\mathrm{Zn}_{15}$ & 5.0 & 4.8 & 41.4 & 41.0 & $9.8 \mathrm{~b}$ & 10.0 \\
\hline \multirow{4}{*}{$\mathrm{P}_{120}$} & $\mathrm{Zn}_{0}$ & 5.0 & 5.1 & 41.9 & 41.7 & $10.1 \mathrm{ab}$ & 10.0 \\
\hline & $\mathrm{Zn}_{5}$ & 5.1 & 4.6 & 41.3 & 42.2 & $9.7 \mathrm{~b}$ & 9.5 \\
\hline & $\mathrm{Zn}_{10}$ & 5.0 & 5.1 & 41.1 & 42.4 & $9.9 \mathrm{~b}$ & 9.5 \\
\hline & $\mathrm{Zn}_{15}$ & 5.0 & 5.1 & 42.0 & 41.7 & $10.7 \mathrm{a}$ & 10.6 \\
\hline \multicolumn{2}{|c|}{$\mathrm{CV} \%$} & 3.37 & 8.41 & 1.62 & 2.16 & 2.11 & 6.57 \\
\hline
\end{tabular}

"Means followed by different letters within columns are significantly different $(\mathrm{p} \leq 0.05)$ ns non-significant

Similar results were reported by Emara (2016) that zinc had no significant effect on ginning outturn. However, Mamatha (2007) observed that zinc application increased the ginning outturn while Ahmad et al. (2009) reported that phosphorus had little effect on ginning outturn. This might be due to the differences in the plant material and the doses of zinc and phosphorus used in the experiments. In addition, climatic conditions might affect the formation and development of fibers and might influence the formation of various Zinc and $\mathrm{P}$ ginning outturns.

\section{Seed Weight $(g)$}

It was observed in Table 6 that there were differences among factors affecting 100 seed weight only in 2011 but not in 2012. In 2011, the lowest 100 seed weight was obtained from the interaction of $\mathrm{P}_{80} \times \mathrm{Zn}_{0}(9.4 \mathrm{~g})$ and the highest 100 seed weight from the interaction of $\mathrm{P}_{120} \times \mathrm{Zn}_{15}(10.7 \mathrm{~g})$. In 2012, the 100 seed weight varied from $9.5 \mathrm{~g}$ to $10.6 \mathrm{~g}$. The presence of the difference between the years might be due to climate and soil factors. Sawan et al. (2001) and Emara (2016) reported that Zn applications increased 100 seed weight. In this case, the increase in 100 seed weight might be due to increasing photosynthesis activity by Zn application (Welch, 1995). 


\section{Conclusion}

Mineral nutrients are one of the most important factor affecting plant growth by contributing the formation of dry matter by affecting the biochemical processes occurring in plants. It was found that phosphorus and zinc management had a significant effect on seed cotton yield, plant height, number of bolls, and number of monopodial branches in both years of the experiment. Both plant nutrients had significant effect on the number of sympodial branches and 100 seed weight only in the first year but not in the second year. These inputs had no significant effect on boll weight, boll seed cotton weight, and ginning outturn in both years.

It was concluded that, depending on the distribution of plant nutrients in the soil, $80-100 \mathrm{~kg}$ of phosphorus and 10-15 kg of Zinc applications per hectare can increase in seed cotton yield. Validity of these results must be verified via multi location tests in future studies.

\section{REFERENCES}

[1] Ahmad, M., Hannan, A., Yasin, M., Ranjha, A. M., Niaz, A. (2009): Phosphorus application to cotton enhances growth, yield, and quality characteristics on a sandy loam soil. - Pakistan Journal of Agriculture Science 46(3): 169-173.

[2] Ahmed, N., Abid, M., Rashid, A. (2010): Zinc fertilization impact on irrigated cotton grown in an aridisol: -Growth, productivity, fiber quality, and oil quality. Communications in Soil Science and Plant Analysis 41: 1627-1643.

[3] Anonymous. (2012a): GAP Agricultural Research Institute Soil Analysis Laboratory Results, Sanliurfa, Turkey.

[4] Anonymous. (2012b): The official record of Meteorology Directory, Adiyaman. The Turkish State Meteorological Service, Turkey.

[5] Aydemir, M. (1982): Cotton Breeding, Cultivation Technique and Fiber Properties Ministry of Agriculture and Forestry General Directorate of Cotton Affairs. - Nazilli Region Cotton Research Institute Publications. No: 33. Nazilli/Aydın, Turkey.

[6] Cakmak, I., Kalayci, M., Ekiz, H., Braund, H. J., Kilinc, Y., Yilmaz, A. (1999): Zn deficiency as a practical problem in plant and human nutrition in Turkey: A NATOScience for stability project. - Field Crops Research 60: 175-88.

[7] Castro, B., Torrent, J. (1995): Phosphate availabilty in calcareous Vertisols and Inceptisols in relation to fertilizer type and soil properties. - Fertilizer Research 40: 109119.

[8] Elwan, I. M., Mohamed, H. Z., Omran, S. E. (2002): Response of cotton plants to phosphaticand zinc fertilization. - Annals Agric. Sci. Cair. 47(3): 1159-1178.

[9] Emara, M. A. A. (2016): Influence of Potassium Fertilization and Spraying of Zinc and Manganese on Cotton Growth and Productivity. - J. Plant Production, Mansoura Univ. 7(10): 1115-1125.

[10] Linsday, W. L., Norvell, W. A. (1978): Development of a DTPA soil test for zinc, iron, manganese and copper. - Soil Sci. Soc. Amer. J. 42: 421-428.

[11] Mamatha, N. (2007): Effect of sulphur and micronutrients (iron and zinc) on yield and quality of cotton in a vertisol. - Department of soil science and agricultural chemistry college of agriculture, Dharwad University of Agricultural Sciences (master thesis) Dharwad. India.

[12] Neilsen, G. H., Hogue, E. J. (1986): Some factors affecting leaf zinc contentration of apple seedling grown in nutrient solution. - Hort. Science. 21: 434-436.

[13] Oosterhuis, D., Hake, K., Burmester, C. (1991): Foliar feeding cotton. - Cotton Physiology. Today 2: 1-7. (Cotton Council of America). 
[14] Oosterhuis, D. M., Bibi, A. C., Gonias, E. D., Mozaffari, M. (2007): Effect of Phosphorus Deficiency on Cotton Physiology. - Summaries of Arkansas Cotton Research 2007. https://www.researchgate.net/publication/242364181.

[15] Ören, Y., Başal, H. (2006): The Effect of Humic Acid and Zinc (Zn) Application on Yield, Yield Componenets and Fiber Quality Parameters in Cotton (Gossypium hirsutum L.). - Journal of Adnan Menderes University Agricultural Faculty 3(2): 77-83.

[16] Panayotova, G., Kostadinova, S., Valkova, N., Pleskuta, L. (2017): Productivity of Cotton Cultivar Darmi Under The Influence of Fertilization at Long-Term Field Trial. AgroLife Scientific Journal 6(1): 178-187.

[17] Prasad, M., Prasad, R. (1994): Response of upland cotton to micronutrients and sulphur. Indian J. Agron. 39(4): 707-708.

[18] Price, C. A. (1970): Molecular Approaches to Plant Physiology. - McGrow Hill Book Co., New York, P.338. USA.

[19] Rathinavel, K., Dharmalingam, C., vam Paneersel, S. (2000): Effect of micronutrient on the productivity and quality of cotton seed cv. TCB 209 (Gossypium barbadense L.). Madras Agricultural Journal 86: 313-316.

[20] Russell, E. W. (2001): Soil Condition and Plant Growth. - The English Language Book Society and Longman. London.

[21] Saleem, M. F., Cheema, M. A., Rasul, F., Bilal, M. F., Anjum, S. A., Wahid, M. A. (2010): Effect of Phosphorus on growth and yield of cotton. - Crop \& Environment 1(1): 39-43.

[22] Sawan, Z. M., Mahmoud, M. H., Momtaz, O. A. (1997): Effect of phosphorus fertilization and foliar application of chelated zinc and calcium on quantitative and qualitative properties of Egyptian cotton. - J. Agric. Food Chem. 45(8): 3326-3330.

[23] Sawan, Z. M., Hafez, S. A., Basyony, A. E. (2001): Effect of nitrogen and zinc fertilization and plant growth retardants on cottonseed, protein, oil yields, and oil properties. - Journal of the American Oil Chemists Society 78: 11.

[24] Sawan, Z. M., Hafez, S. A., Ahmed, E. B., Alkassas, Abou-El-Ela, R. (2006): Cottonseed, protein, oil yields and oil properties as influenced by potassium fertilization and foliar application of zinc and phosphorus. - World Journal of Agricultural Sciences 2(1): 66-74.

[25] Sawan, Z. M., Mahmoud, H. M., Amal, H. E. G. (2008): Influence of potassium fertilization and foliar application of zinc and phosphorus on growth, yield components, yield and fiber properties of Egyptian cotton (Gossypium barbadense L.). - Journal of Plant Ecology 1(4): 259-270.

[26] Sawan, Z. M. (2018): Mineral fertilizers and plant growth retardants: Its effects on cottonseed yield; its quality and contents. - Cogent Biology 4(1): 1459010.

[27] Sharma, J. C., Gupta, V. K. (1988): Effects of zinc application on yield and zinc concentration of different parts of cotton plant. - Environ. Ecol. 5: 257-260.

[28] Singh, S. K., Badgujar, G. B., Reddy, V. R., Fleisher, D. H., Timlin, D. J. (2013): Effect of phosphorus nutrition on growth and physiology of cotton under ambient and elevated carbon dioxide. - Journal of Agronmy and Crop Science 199: 436-448.

[29] Soomro, A. W., Soomro, A. R., Leghari, A. B., Chang, M. S., Soomro, A. H., Tunio, G. H. (2000): Effect of Boron and Zinc Micronutrients on Seedcotton Yield and its Components. - Pakistan Journal of Boilogical Science 3(12): 2008-2009.

[30] Stewart, W. M. (1998): Fertilize Cotton for Optimum Yield Quality. - News \& Views. A regional newsletter published by the Potash \& Phosphate Institute (PPI) and the Potash \& Phosphate Institute of Canada (PPIC).

[31] Şenel, M. (1980): Cotton breeding, cultivation and technology. - Ministry of Agriculture Regional Research Institute. Publication No: 36, Adana, Turkey.

[32] Weir, B. L., Kerby, T. A., Hake, K. D., Roberts, B. A., Zelinski, L. J. (1996): Cotton Fertility. Cotton Production Manual. - University of California. Division of Agricultural and Natural Resources. Publication No: 3352. 
[33] Welch, R. M. (1995): Micronutrient nutrition of plants. - CRC Critical Reviews in Plant Science 14: 49-82.

[34] Worley, S. J. R., Harmon, H. R., Harrel, D. C., Culp, T. W. (1976): Ontogenetic Model of Coton Yield. - Crop Science 16: 30-34.

[35] Zhou, M., Li, Y. (2001): Phosphorus-Sorption Characteristic of Calcareous Soils and Limestone from the Southern Everglades and Adjacent Farmlands. - Soil Sci. Soc. Am. J. 65: 1404-1412. 